\title{
THE EFFORTS OF SOCIAL SERVICES AND POVERTY TREATMENT IN ADDRESSING STREET CHILDREN IN BANDUNG CITY
}

\author{
Rira Nuradhawati \\ Universitas Jenderal Achmad Yani \\ Jl. Terusan Jend. Sudirman, Cibeber, Kec. Cimahi Sel., Kota Cimahi, Jawa Barat 40531, Indonesia \\ Correspondence Email: rira.nuradhawati@lecture.unjani.ac.id
}

Submitted: 08-09-2020, Reviewed: 20-09-2020, Published: 30-10-2020

\begin{abstract}
Living as street children is not a pleasant choice, because they are in conditions with no clear future, and their existence often becomes a "problem" for many parties, families, communities and the state. According to the 1945 Constitution, "abandoned children are cared for by country". By the Minister of Social Affairs Regulation Number 08 of 2012 Article 1 paragraph (8) concerning the Implementation of social welfare is a directed, integrated and sustainable effort carried out by the Government, regional government and the community in the form of social services to meet the basic needs of every citizen. which includes social rehabilitation, social security, social empowerment, and social protection. This study aims to obtain a comprehensive picture of how Dinsosnangkis City of Bandung's efforts to deal with street children. This research uses a descriptive qualitative approach. The results showed that in the context of policy content and the implementation of human and financial resources, it is very influential on the achievement of policy objectives and resource factors, especially financial, in this case, the budget becomes an obstacle in the implementation of Dinsonsnangkis policy in dealing with street children in Bandung City.
\end{abstract}

Keywords: Effort, implementation, policy, street children

\begin{abstract}
ABSTRAK
Hidup menjadi anak jalanan memang bukan merupakan pilihan yang menyenangkan, karena mereka berada dalam kondisi yang tidak bermasa depan jelas, dan keberadaan mereka tidak jarang menjadi "masalah" bagi banyak pihak, keluarga, masyarakat dan negara Menurut UUD 1945, "anak terlantar itu dipelihara oleh negara". Sesuai dengan Permensos Nomor 08 Tahun 2012 Pasal 1 ayat (8) tentang Penyelenggaraan kesejahteraan sosial Penyelenggaraan kesejahteraan sosial adalah upaya yang terarah, terpadu, dan berkelanjutan yang dilakukan Pemerintah, pemerintah daerah, dan masyarakat dalam bentuk pelayanan sosial guna memenuhi kebutuhan dasar setiap warga negara, yang meliputi rehabilitasi sosial, jaminan sosial, pemberdayaan sosial, dan perlindungan sosial. Penelitian ini bertujuan untuk memperoleh gambaran yang komprehensif bagaimana upaya Dinsosnangkis Kota Bandung dalam upayanya menangani anak jalanan. Penelitian ini menggunakan pendekatan deskriptif kualitatif. Peneliti menggunakan pendekatan deskriptif kualitatif. Hasil penelitian menunjukkan bahwa dalam konteks isi kebijakan dan implementasi sumberdaya manuisa dan finansial sangat berpengaruh terhadap pencapaian tujuan dari kebijakan dan fakto sumberdaya terutama finansial dalam hal ini anggaran menjadi penghambat dalam implementasi kebijakan Dinsonsnangkis dalam menangani anak jalanan di Kota Bandung.
\end{abstract}

Kata Kunci: Upaya, implementasi, kebijakan, anak jalanan

\section{BACKGROUND}

According to the 1945 Constitution, "abandoned children are cared for by the state". This means that the government has the responsibility for the care and guidance of abandoned children, including street children. The rights of neglected children and street children are essentially the same 
Vol.6, No.2, 2020

Doi: https://doi.org/10.24198/cosmogov.v6i2.29387

http:/jurnal.unpad.ac.id/cosmogov/index

as human rights in general, as stated in Law no. 39 of 1999 concerning Human Rights, and Presidential Decree No. 36 of 1990 concerning Ratification of the Convention on the Right of the Child (Convention on the Rights of the Child). They need to get their rights normally like children, namely civil rights and freedoms, family environment and choice of care (family environment and alternative care), basic health and welfare, education, recreation and culture (education, leisure and culture activities), and special protection (special protection).

In guaranteeing the rights mentioned above, the Government has poured it into a policy in the form of Child Protection Law number 23 of 2002 which explains that every child is a potential bud, and the younger generation is the successor of the nation's ideals, has a strategic role and has characteristics and characteristics. Specifically, that guarantees the continuity of the Nation and the State's existence in the future; therefore, it is necessary to obtain the widest possible opportunity to grow and develop optimally both physically, mentally and socially.

The form of the role of the Government and society's responsibility in carrying out the handling of street children is stated in Law No. 23 of 2002 Article 4 concerning Child Protection states that:

"The government and the community carry out child handling through the development centre for street children services, child social homes, shelters, child protection houses, learning houses, community learning activity centres, through social organizations, foundations and non-governmental organizations (NGOs).
"The results of the National SocioEconomic Survey (SUSENAS) of the Central Bureau of Statistics of the Republic of Indonesia in 1998 showed that there were around 2.8 million street children nationally. In 2000, this figure had increased by around $5.4 \%$, so that the number became 3.1 million children. In the same year, there were 10.3 million children classified as vulnerable to becoming street children or $17.6 \%$ of Indonesia's child population, namely 58.7 million children (Soewignyo, 2010 in M. Yusuf Agung S. and Moh. Mansur Fauzi, 2018).

These figures show that the quality of life and future of the children is very worrying, even though they are an asset, an investment in human resources and at the same time a foundation for the future of the nation. If our children's condition and quality of life are a concern, it means that the future of the nation and state is also less satisfying. In fact, some of our nation's children may have experienced lost generation.

In fact, it could be that the number of street children in the field is much greater, this shows that the problem of street children is an iceberg phenomenon, which from year to year has increased both in number and in the area of its spread. On the other hand, street children's problem is a social pathology that affects children's behaviour, with patterns and sub-cultures that develop on the streets as an attraction for children who still live at home but are vulnerable to becoming street children, to take to the streets. The tendency is that if there is no effort to overcome it, it is not just going down, but gradually working and living on the road merges with other street children. 
Vol.6, No.2, 2020

Doi: https://doi.org/10.24198/cosmogov.v6i2.29387

http://jurnal.unpad.ac.id/cosmogov/index

The handling of street children in all Indonesia regions generally does not have the right and effective model and approach. The existence of a shelter for example, according to research results from the Social Development and Training Agency of the Ministry of Social Affairs (2003), is considered ineffective because it does not touch the root of the problem, namely poverty in the family "(Kompas, 26 February 2003 in Rifanto Bin Ridwan which published in the journal of Tsaqofah, 2012).

In terms of coaching, empowerment also in the family environment where they live has not been widely implemented, which in the end it appears that the policy for handling street children itself tends to be patchy so that it can be said to be ineffective because it only addresses the problem for a while. On the other hand, we all know that the family is the centre of education, fostering and first empowering a child who can influence the child's growth and development to be good, healthy and smart.

Family empowerment of street children, especially in terms of economy, education and religion (Putra, Hasanah and Nuriyah, 2018). It can be said that empowerment is the main basis and a fairly effective model for the handling and empowerment of street children.

The number of street children, beggars, and people with disabilities can be found easily on several roads in Bandung. Children's involvement in the streets, both for playing and looking for sustenance is common in their lives. However, unfortunately, without them realizing that their existence on the streets endangers them from all kinds of threats on the streets, such as accidents, drug use, free sex, and other threats that can interfere with their growth and development. The children took to the streets, among others, because of family disharmony, wrong care in the family, and even from the government's unpreparedness in providing facilities and infrastructure.

In Bandung itself, according to data obtained by researchers from the Social and Poverty Prevention and Poverty Alleviation Office of Bandung City, the number of street children in 2012 to 2014 reached 5,590, and from 2014 to 2017 it reached 4,949 children.

Seeing this condition, it is very worrying because, in the midst of the city's very rapid development, street children have sprung up everywhere. The current development of the city of Bandung seems to provide positive nuances for people's lives. However, it also gave birth to life competition, so that the phenomenon of life that led to poverty emerged. A densely populated city and many problematic families ultimately lead to more and more malnourished children, lack attention, lack of education, lack compassion and warmth, and lose the right to play, have fun, have a community and live independently. This causes the emergence of street children in the city of Bandung to increase so that further handling is needed and the increasing growth of street children.

By the Minister of Social Affairs Regulation Number 08 of 2012 Article 1 paragraph (8) concerning the Implementation of social welfare is a directed, integrated and sustainable effort carried out by the Government, regional government and the community in the form of social services to meet the basic needs of 
Vol.6, No.2, 2020

Doi: https://doi.org/10.24198/cosmogov.v6i2.29387

http://jurnal.unpad.ac.id/cosmogov/index

every citizen. which includes social rehabilitation, social security, social empowerment, and social protection. Persons with Social Welfare Problems (PMKS) according to the Minister of Social Affairs No. 08/2012 Article 1 paragraph (3) concerning Persons with Social Welfare Problems, hereinafter referred to as PMKS, are individuals, families, groups, and/or communities due to obstacles, difficulties or disturbances. , cannot carry out their social functions, so their daily needs both physically, spiritually and socially cannot be adequately and fairly.

According to Grindle (Leo Agustino 2016: 142) identifies two things that can provide a successful policy implementation, namely: "Content of policy and context of implementation." a policy. Context of implementation can be defined as an attempt to see how or to what extent the political context (structure and dynamics) affects government policies' implementation. No matter how good a policy is, if at the stage of its implementation, it is heavily influenced by political interests that take place among the elites then the policy will not be implemented properly as expected.

The policy carried out by the Bandung City Office of Social and Poverty Alleviation in dealing with street children returns the children to their parents and their schools. The implementation is in the form of a program, and the program is guiding neglected children, where this program has several activities:

1. Skills training and practical worklearning training for street children

2. Activities to develop the talents and skills of abandoned children.
3. To improve the skills of assisting neglected children.

4. Monitoring and evaluation and reporting of the forms of street children activities carried out by RPA.

5. Services for the results of street children through empowering parents.

6. To improve the quality of services, facilities and infrastructure for children's social services.

7. Skills activities and work-learning practices for school dropouts. Implementation has coordinated with RPA, meeting with RPA. Until now, street children are still needed.

However, these legal instruments and policies have not been implemented properly because the reality on the ground shows that the rights as stated in the convention on children's rights and the laws that regulate them have not been fully obtained by street children, parents are indeed the main party to provide rights to their children, but due to the unsupportive economic conditions of the family, the role of the Government, especially through the Social and Poverty Alleviation Office, is obliged to provide the rights that street children should have.

\section{METHOD}

This study uses a qualitative descriptive approach, an approach in which information or data is collected, formed or composed of words and images, not numbers (Moleong: 2013).

Researchers used a qualitative descriptive approach because the problems 
Vol.6, No.2, 2020

Doi: https://doi.org/10.24198/cosmogov.v6i2.29387

http://jurnal.unpad.ac.id/cosmogov/index

to be discussed were not based on numbers but in words. These words can come from the results of interviews, observations and documentation. In this study, the researcher intends to describe how the Bandung City Social and Poverty Alleviation Service

\section{RESULTS AND DISCUSSION}

\section{Dinsosnangkis Of Bandung City Policy} in Policy Contents

According to Friedrick in (Winarno, 2012: 16) which defines policy as:

"A direction of action proposed by a person, group or government in a certain environment by showing the obstacles and opportunities for the proposed policy to use and overcome in order to achieve a goal or realize a particular goal or purpose".

Making public policy is a complex process because it involves many processes and variables that must be studied. Therefore, some political experts interested in studying public policy divide the processes of formulating public policies into several stages.

Public policy stages, according to William N Dunn (2013: 24). It is as follows:

1. Agenda setting.

2. Policy formulating. At this stage the problems are

3. Policy Adoption / Legitimacy (Policy Adoption).

4. Policy Implementation.

5. Assessment / Policy Evaluation (Policy Evaluation).

Based on Dunn's thought, there is a stage of policy implementation in the stages of public policy. policies are implemented in dealing with street children in Bandung.

The data collection method in this study uses several ways to obtain valid or valid data. The method used is observation/observation, interviews, and documentation.

The definition of implementation, according to Purwanto and Sulistyastuti (2012: 58), is:

"Policy implementation as a process, a series of substantial decision and action directed toward putting a prior authoritative federal decision into effect" (Implementation of policy as a process, a series of decisions and important actions directed in making decisions by the government that have the impact of these decisions. )

Marilee. S Grindle (Leo Agustino 2016: 142) identifies two things that can provide a successful policy implementation, namely: "the content of the policy and the context of its implementation". The basic idea is that after policies are transformed, only then can policy implementation be carried out. Its success is determined by the degree of policy implementation. The contents of the policy include the following:

1. Interest Affected (interests that are affected by the policy). relating to various interests that influence policy implementation. This indicator argues that in its implementation, a policy must involve many interests and how these interests influence its implementation.

2. Type of Benefits: At this point, the content of policy seeks to show or explain that there must be several types of benefits 
Vol.6, No.2, 2020

Doi: https://doi.org/10.24198/cosmogov.v6i2.29387

http:/jurnal.unpad.ac.id/cosmogov/index

in a policy that indicate the positive impact generated by the implementation of the policy to be implemented.

3. Extent of change Envision (degree of change desired) Each policy has targets to be and want to be achieved. The content of policy that you want to explain at this point is that how much change you want or want to achieve through a policy implementation must have a clear scale.

4. Site of Decision Marking (location of decision making) Decision making in a policy plays an important role in implementing a policy, so this section should explain where the decision making of a policy will be implemented.

5. Program Implementer (Who is the implementer of the Program) In carrying out a policy or program, it must be supported by a competent and capable policy implementation for the success of a policy. This must have been properly recorded exposed in this section.

6. Resources Committed (resources used) The implementation of a policy must also be supported by supporting resources so that its implementation runs well.

Grindle stated that it is related to various kinds of interests that influence a policy. Likewise, with Dinsosnangkis in implementing policies related to handling street children.

Based on Bandung City Regional Regulation No. 18 of 2016 concerning the Formation and Organizational Structure of Bandung City Regional Offices, Dinsosnangkis has the duty and obligation to assist the Mayor in carrying out social welfare affairs.

Furthermore, in Law Number 4 of 2019 the amendment to Law Number 10 of
2012 concerning the Application of Child Protection Article 2 that: "The implementation of child protection and development of KLA based on Pancasila and the 1945 Constitution as well as the basic principles of the Convention on the Rights of the Child."

The policy regarding street children based on the two regulations and laws above regulates some control and development provisions.

The purpose of the child protection policy living on the street as described above is to alleviate or withdraw children from life on the street and ensure the fulfilment of children's rights to live, grow, develop, and adapt as normal children are generally suitable with their dignity as human beings and to provide protection from the harshness of life on the streets which are full of violence, exploitation and crimes that are vulnerable to threatening them.

Meanwhile, the target of child protection policies living on special roads in Bandung City is known as people with social welfare problems or known as PMKS. PMKS itself is a person, family or community group who due to an obstacle, difficulty or disturbance, cannot carry out their social functions so that their life needs (physical, spiritual and social) cannot be fulfilled adequately and fairly.

Based on the results of interviews with the head of the UPT who handles street children, the opinion is that street children are those who have social problems where they cannot benefit from those around them and cannot provide benefits to those around them.

Therefore, the Office of Social Affairs and Poverty Alleviation in the City 
Vol.6, No.2, 2020

Doi: https://doi.org/10.24198/cosmogov.v6i2.29387

http://jurnal.unpad.ac.id/cosmogov/index

of Bandung formulates and implements policies whose contents are improving social services for street children. This policy aims to foster street children and provide skills training so that their lives can be better. Apart from that, this policy is also intended to instil awareness and social responsibility of street children to participate in social processes in society when they return to normal social interactions in general.

The formulation of a policy based on the Minister of Social Affairs No. 08 of 2012 on Guidelines for Data Collection and Data Management of Persons with Social Welfare Problems and Potential and Sources of Social Welfare, then the policy is outlined in a variety of programs or activities that are none other than to improve social services for street children caused by increasing population of street children in the city of Bandung.

Based on the results of field observations, it appears that street children are not children who live on the streets, but many of them still have parents. Family economic factors cause them to take to the streets as hawkers, street singers and even beggars. In the city of Bandung, the gathering points are usually at the traffic lights around Leuwi Panjang, Bandung Station, Jalan Seram, and many more. However, generally, they gather on roads that are quite busy with people. From the field data, it is found that the majority of street children are of school age.

This is what makes Bandung City Dinsosnangkis need to make policies in dealing with this phenomenon. Programs to improve social services for street children are intended not only for Bandung but also for migrants from other areas. Based on the results of interviews with social counsellors on 28 November 2019, we know that Social Response Unit Team consisting of Social volunteers always doing something promotive with the existence of "war" or announcements, the meaning is that this team always goes around in Bandung to invite the public to be involved in handling these street children not to give money to street children. Also, Dinsonangkis Bandung has social counsellors who provide social counselling related to the program.

Social instructors are part of the most important resources in determining an implementation process. If the human resources in an organization lack numbers, then the organization's activities will not run optimally. On the other hand, human resources must also have the competence and capability to optimally carry out organizational activities.

Based on the interviews with the head of the UPT, it can be seen that to provide guidance or guidance to street children, and there is the involvement of social workers.

Social workers themselves are professionally involved in efforts to help individuals, groups or communities increase and improve their capacity and social function so that they can create better social conditions.

According to the interview results with a social worker, they are required to have an academic or educational background from the social welfare department. They are also required to position themselves as part of those who have problems with their social functions such as street children. 
Vol.6, No.2, 2020

Doi: https://doi.org/10.24198/cosmogov.v6i2.29387

http://jurnal.unpad.ac.id/cosmogov/index

When conducting counselling as part of the implementation of street children's policies, a social worker often acts like street children to provide information and find motives for why they go to the streets.

When communicating with street children is not as easy as we imagine, because usually street children when invited to communicate they have a powerful weapon, namely lying, which according to the researcher's view that street children have their own world that is different from our world as humans who have no problems as they experienced.

Usually, when asked to talk, their talk will go round and round. However, social workers or social workers are observant enough to draw a common thread from what street children are talking about, such as when trying to find out where they come from, usually the children will discuss or talk. About the same thing and repeating itself but at another time it will change, the social worker itself does not force them to talk, but draws a common thread, for example, a street in one area by showing street children through the google maps application, so that when the street child see, they seem restless, and from that situation and condition it is possible to find out where he came from because he can no longer escape.

From what the informants stated, it seems that becoming a social worker or social worker is not easy, because the social worker himself is like a doctor or psychologist who is required to diagnose precisely what is the source of the illness of his patient so that the right medicine prescription can be made to help, in the process of healing.
In implementing policies as described above, human resources as implementers such as one of the extension agents or social workers are expected to support the ongoing process of policies by increasing apparatus resources by controlling starting from the apparatus and resources' professional performance. The budget, which is a means of achieving goals, is often associated with efficient methods and systems. The process takes place on time so that it is clear that it is logical and appropriate to increase resources as one of the institution's long-term goals in implementing its work strategy. By the vision and mission, it has.

Apparatus who have high creativity will produce the quality that concerns all types of activities organized by the Dinsosnangkis of Bandung City, both executing main tasks and executing supporting tasks, quality improvement is not only important internally, but also externally because it will be reflected in interactions organization with its environment which in turn helps shape the image of the organization in the eyes of various parties such as the government and society as well as the Bandung City Social Service. Researchers feel that the use of working time for the Dinsosnangkis Apparatus of the City of Bandung is still not optimal because there are still some less disciplined officers, which obstructs the of the Dinsosnangkis of Bandung City because of a lack of professionalism in their performance.

Furthermore, in Dinsosnangkis of Bandung, researchers feel that there is still a lack of apparatus who have high competence and creativity in solving social welfare problems. It can hinder the success of programs that are precise and right on 
Vol.6, No.2, 2020

Doi: https://doi.org/10.24198/cosmogov.v6i2.29387

http:/jurnal.unpad.ac.id/cosmogov/index

target, in handling empowerment for street children in particular who also involve the community in handling them, and people with social welfare problems (PMKS), especially beggars, vagabonds, and street children in general. The city of Bandung, which has been contained in one of the duties and functions of the City of Bandung Dinsosnangkis, namely, the formulation of technical policies in the social sector, the implementation of some government affairs and public services in the social sector, guidance and implementation of tasks in the social sector including social and community participation, social rehabilitation, social services and social vulnerable development.

\section{Dinsosnangkis Of Bandung City Policy in the Context of Policy Implementation}

Service quality can include many negative views formed regarding the role of Dinsosnangkis, where the emergence is due to the factor of public dissatisfaction with the quality of service provided by Dinsosnangkis. Thus, the satisfaction of the community can become a benchmark for assessing the performance of Dinsosnangkis.

The level of apparatus compliance as quality service in dynamic conditions related to products, services, people, processes and the environment that meet or may exceed expectations. Service quality is also defined as something related to the fulfilment of expectations or needs of the people of Bandung City as customers, for the achievements of Dinsosnangkis in handling beggars, vagabonds, and street children.
The commitment or level of compliance of the Dinsosnangkis apparatus will determine the good or bad quality of service from the Bandung City Dinsosnangkis which in turn will determine the views or satisfaction of the Bandung City community on the performance of the Dinsosnangkis performance. This is due to the Dinsosnangkis working to solve social welfare problems in the city of Bandung, so the community is ensured to see the environment directly around them to provide an assessment of the performance of Dinsosnangkis in solving social welfare problems in the city of Bandung, especially in problems of Street children.

In this case, the level of apparatus compliance and the apparatus's ability can show performance in carrying out the objectives, namely the Implementation and Management of Social Welfare. Dinsosnangkis is required to be able to recognize the various characteristics of people with social welfare problems, especially street children in the city of Bandung, which aims to facilitate the work of Dinsosnangkis in providing good response to solve the problems of street children in Bandung, which are considered to be increasing in number.

As for the point of one of Dinsosnangkis Strategic Plan, there is one point that the researchers underline, namely increasing the capacity and quality of services for PMKS carried out by the Potential and Sources of Social Welfare (PSKS), especially the guidance of Youth Organizations, Community Participation and Social Organizations which are very large in number. In the city of Bandung. From these points, it appears that there are 
Vol.6, No.2, 2020

Doi: https://doi.org/10.24198/cosmogov.v6i2.29387

http://jurnal.unpad.ac.id/cosmogov/index

efforts to involve social and community participation, where it is hoped that there will be an active role from the community in comprehensively handling social welfare problems.

Social welfare is the will of the whole community. It is related to the level of compliance of the apparatus, which describes the ability to meet the community's needs, which is coupled with intensive giving to the apparatus to improve the performance of the apparatus and beggars vagabonds, street children and their families. In the case of handling beggars, vagabonds, and street children, social assistance is also needed, namely a process of handling carried out to the families of street children or it can also be referred to as a social assistance program for families of street children in the form of pieces of training, providing business loans but not carried out free of charge, providing business loans requires intensive supervision related to the poor.

Then Dinsosnangkis as the executor of the policy must know what should be done and have the desire to implement a policy.

Standard operating procedures of the Bandung City Social Service in carrying out the implementation of bureaucratic policies as implementers must support the Ministry of Social Affairs policy No. 8 of 2012 by coordinating well and distributing responsibility or fragmentation of established policies.

In the framework of operationalizing the program, it includes efforts to realize social welfare through increasing social and community participation, where there is an active role of the community in handling social welfare problems comprehensively, realizing social welfare through increased social rehabilitation in order to restore community powerlessness in carrying out social functions, realizing social welfare through improving social services, which implies the optimization of services for Persons with Social Welfare Problems, realizing social welfare through enhancing the development of social vulnerability for families and children. So that those who fall into the category of PMKS where they experience social dysfunction are expected to be able to carry out their social functions properly, be carried out in the family, community and social institutions and be carried out in the form of motivation and psychosocial diagnosis which is usually carried out by social workers, then the treatment or care of street children by being appointed as foster children by the community with financial assistance, especially for obtaining an education. Giving skills can be carried out in a shelter or temporary shelter or by involving youth organizations or NGOs interested in social problems. Based on results interviews with social counsellors noted that providing mental and spiritual guidance to fill in the emptiness of street children who do have their own world.

Then, social security is provided in the form of social welfare insurance, continuous, direct assistance and sustainable benefits by statutory regulations. Social protection is intended to prevent and deal with risks from shocks and social vulnerability of people with social welfare problems to survive. Fulfilled according to minimum basic needs. Implemented through the provision of assistance, 
Vol.6, No.2, 2020

Doi: https://doi.org/10.24198/cosmogov.v6i2.29387

http://jurnal.unpad.ac.id/cosmogov/index

advocacy and legal assistance, and empowered to meet their needs independently and increase the participation of individuals and institutions as potentials and resources in the implementation of social welfare.

Based on the explanation above regarding the implementation context that supports policy implementation's success, there must be a fixed procedure for policy actors in implementing their policies and responsibility in carrying out a policy to achieve the goals to be achieved. In principle, policy implementation is nothing less than how a policy can achieve its goals.

\section{Inhibiting Factors in the Implementation of Dinsosnangkis Policy Of Bandung City in Handling Street Children}

From the results of observations and interviews, it can be seen that the inhibiting factor in the implementation of Dinsosnangkis policy in dealing with the problem of street children is the budget factor or financial resources. Given the limitations in terms of budget, the implementation of a program will experience obstacles that hinder the achievement of the goals that have been set earlier.

With budget constraints, when the coaching program and skills provision have been provided, it will be useless when the street children return to the streets due to economic factors. Because without capital support for them to open a business to meet their daily needs, street children prefer to return to the streets because it is easier to get rupiah coffers.
Besides, some street children and even people still do not understand or do not know about the existence of a program from Dinsosnangkis related to PMKS handling, one of which is street children. It will also hinder efforts to achieve goals.

Another inhibiting factor is the lack of public awareness and concern for the social problems that surround them. If the community has awareness and concern that it might be able to suppress and even reduce the number of street children, the problem of street children also arises because the family cannot function properly, even though the family is like a miniature state, national resilience departs from community resilience, as well as the resilience of the departing community. From family resilience. So efforts are needed to optimize the role of the family.

\section{CONCLUSION}

From the research results related to the implementation of the policy of Dinsosnangkis in dealing with street children are as follows: First, In implementing the policy, Dinsosnangkis relies on the Minister of Social Affairs No. 08 of 2012 concerning Guidelines for Data Collection and Data Management of Persons with Social Welfare Problems and Potentials and Sources of Social Welfare in order to provide protection, counselling, services, social rehabilitation, guidance and skills development to street children as objectives of the policy.

The purpose of the child protection policy living on the street is to alleviate or 
Vol.6, No.2, 2020

Doi: https://doi.org/10.24198/cosmogov.v6i2.29387 http://jurnal.unpad.ac.id/cosmogov/index

withdraw children from life on the streets, ensure the fulfilment of children's rights so that they can live, grow, develop and adapt as normal children, in general, are by their dignity as human beings. and to provide protection from the harshness of life on the streets which are full of violence, exploitation and crimes that are vulnerable to threatening them.

Meanwhile, the target of child protection policies living on special roads in Bandung City is known as people with social welfare problems or known as PMKS. PMKS itself is a person, family or community group who due to an obstacle, difficulty or disturbance, cannot carry out their social functions so that their life needs (physical, spiritual and social) cannot be fulfilled adequately and fairly. The Office of Social Affairs and Poverty Alleviation in the City of Bandung formulates and implements policies that include improving street children's social services.

This policy aims to foster street children and provide skills training so that their lives can be better. Apart from that, this policy is also intended to instil awareness and social responsibility of street children to participate in social processes in society when they return to normal social interactions in general.

In its implementation, Dinsosnangkis has a social response team, which includes social counsellors and social workers to help those who are part of the PMKS group to return to function properly in social matters.

In terms of human resources, there are still less disciplined apparatus. In contrast, support in terms of infrastructure facilities is good enough that it is hoped that it will support the achievement of work goals and objectives owned by Dinsosnangkis. However, do not forget also support in terms of the budget of a program because it determines the program's success. By prioritizing work professionalism more and more, Bandung City's Dinsosnangkis Apparatus Resources are supported by adequate facilities and budget, so the progress is going well in terms of the Implementation and Management of Social Welfare in the City of Bandung, especially in handling street children.

In carrying out its duties, Dinsosnangkis coordinates with the Satpol PP, the Transportation Service, the Education Office, the Population and Civil Registry Service, and the Health Service. In implementing the policy, Dinsosnangkis also tries to involve the community to appeal to the community not to give anything to street children. The commitment or level of compliance of Dinsosnangkis apparatus will determine the good or bad quality of service from Dinsosnangkis, which will determine the Bandung City community's views or satisfaction Dinsosnangkis performance. This is due to the Bandung City Dinsosnangkis working to solve social welfare problems in the city of Bandung, so the community is ensured to see the environment directly around them to provide an assessment of the performance of Dinsosnangkis in solving social welfare problems in the city of Bandung, especially in problems Street children. In this case, the level of apparatus compliance and the apparatus's ability can show performance in carrying out the objectives, namely the Implementation and Management of Social Welfare. Dinsosnangkis is required to 
Vol.6, No.2, 2020

Doi: https://doi.org/10.24198/cosmogov.v6i2.29387

http://jurnal.unpad.ac.id/cosmogov/index

recognize the various characteristics of people with social welfare problems, especially street children in Bandung, which aims to facilitate the work of Dinsosnangkis in providing a good response to solve the problems of street children in Bandung, which are considered to be increasing in number.

Second, when the coaching program and skills provision have been provided with budget constraints, it will be useless when the street children return to the streets due to economic factors. Because without capital support for them to open a business to meet their daily needs, street children prefer to return to the streets because it is easier to get rupiah coffers. Also, some street children and even people still do not understand or do not know about

\section{REFERENCES}

Agus, Erwan Purwanto dan Dyah Ratih Sulistyastuti. 2012. Implementasi Kebijakan Publik. Konsep dan Aplikasinya di Indonesia. Yogyakarta : Gava Media

Agustino, Leo. 2016. Dasar-Dasar Kebijakan Publik. Bandung. Alfabeta.

B Winarno, 2012, Kebijakan Publik, CAPS, Yogyakarta

Dunn, William N. 2012. Analisis Kebijaksanaan Publik, Yogyakarta :PT. Hanindita Graha Widya

Keputusan Presiden RI No. 36 Tahun 1990 tentang Pengesahan Convention on the Right of the Child (Konvensi tentang hak-hak Anak).

Lexy J Moleong, 2013, Metode Penelitian Kualitatif (Bandung: PT. Remaja Rosdakarya, the existence of a program from Dinsosnangkis related to PMKS handling, one of which is street children. It will also hinder efforts to achieve goals. Another inhibiting factor is the lack of public awareness and concern for the social problems that surround them. If the community has awareness and concern that it might be able to suppress and even reduce the number of street children, the problem of street children also arises because the family cannot function properly, even though the family is like a miniature state, national resilience departs from community resilience, as well as the resilience of the departing community. From family resilience. So efforts are needed to optimize the role of the family.

M. Yusuf Agung dan Moh Mansur Fauzy, 2018, Pendidikan Anak Jalanan Dalam Paradigma Teo-AntropoSosiosentris, Jurnal Piwulang, Vol. I No. 1 September 2018, 90-104 90 https://e-journal.staimaalhikam.ac.id/index.php/piwulang/ article/download/158/142, diakses tanggl 07 Januari 2020, pukul 22.15

UUD 1945

UU No. 39 tahun 1999 tentang Hak Asasi Manusia,

Undang-Undang Perlindungan Anak nomor 23 tahun 2002

Peraturan Daerah Kota Bandung Nomor 24 Tahun 2012 tentang Penanganan Penyandang Kesejahteraan Sosial (PMKS)

Permensos No 08 Tahun 2012 tentang Pedoman Pendataan Dan Pengelolaan Data Penyandang Masalah Kesejahteraan Sosial Dan 
Vol.6, No.2, 2020

Doi: https://doi.org/10.24198/cosmogov.v6i2.29387

http://jurnal.unpad.ac.id/cosmogov/index

Potensi Dan Sumber Kesejahteraan Sosial

Putra, Hasanah and Nuriyah in Share Social Work Journal, vol 05 No 1 , http://jurnal.unpad.ac.id/share/articl e/download/13118/5976, accessed on January 8, 2020, at 0.45 WIB

Rifanto Bin Ridwan which published in the journal of Tsaqofah_Vol. 8, No. 2,
Oktober 2012

https://ejournal.unida.gontor.ac.id/i ndex.php/tsaqafah/article/downloa $\mathrm{d} / 26 / 26$, accessed on January 7 , 2020, at 22.32 WIB

Soedijar, Z.A, Penelitian Profil Anak Jalanan di DKI Jakarta. Jakarta: Badang Penelitian dan Pengembangan Sosial Departemen Sosial 